\title{
Penegakan Hukum Tindak Pidana Prostitusi Online di Surabaya
}

\author{
Kurniadi Prasetyo ${ }^{1}$ \\ ${ }^{1}$ Fakultas Hukum Universitas Yos Soedarso Surabaya \\ E-mail: kurniadiprasetyo82@gmail.com
}

\begin{abstract}
The prostitution crime in Indonesia, especially in Surabaya, is getting higher. With the closure of Dolly's prostitution area, the providers of prostitus services use the internet to open their services. The use of the internet as a prostitution service is often called online prostitution. Problems regarding the crime of online prostitution in Surabaya are regulated in article 27 paragraph (1) of Law no. 11 of 2008 concerning Information and Electronic Transactions; Article 45 paragraph (1) of Law No. 19 of 2016 concerning Information and Electronic Transactions; Article 27 Paragraph (1) Law No. 1 of 2018 concerning Electronic Information and Transactions; Article 4 paragraph (2) of Law No. 44 of 2008 concerning Pornography; Article 4 paragraph (2) of Law No. 44 of 2008 concerning Pornography; article 296 of the Criminal Code; Article 506 of the Criminal Code; Article 37 paragraph (2) of Surabaya City Government Regulation No. 2 of 2014 concerning Implementation of Public Order and Community Peace. In law enforcement, online prostitution crime in Surabaya does not only tend to impose sanctions in accordance with article 27 paragraph (1) of the Information and Electronic Transaction Law. However, the City Government of Surbaya is trying to implement prevention of trafficking in persons suspected of having links to online prostitution. In the policy to prevent trafficking in persons, the Surabaya city government has implemented two prevention systems, namely Preemtif Prevention and Preventive Prevention.
\end{abstract}

Keywords: Criminal Act, Online Prostitution, Law Enforcement

\begin{abstract}
Abstrak
Tindak pidana prostitusi di Indonesia khususnya di Surabaya semakin tinggi. Dengan ditutupnya kawasan prostitusi Dolly membuat para penyedia jasa prostitusi menggunakan media internet untuk membuka jasanya. Penggunaan internet sebagai layanan jasa prostitusi sering kali disebut prostitusi online. Permasalahan mengenai tindak pidana prostitusi online di Surabaya diatur dalam Pasal 27 ayat (1) Undang-Undang No. 11 Tahun 2008 tentang Infomarsi dan Transaksi Elektornik; Pasal 45 ayat (1) Undang-Undang No. 19 Tahun 2016 tentang Informasi dan Transaksi Elektronik; Pasal 27 ayat (1) Undang-Undang No. 1 Tahun 2018 tentang Informasi dan Transaksi Elektronik; Pasal 4 ayat (2) Undang-Undang No. 44 Tahun 2008 Tentang Pornografi; Pasal 4 ayat (2) Undang-Undang No. 44 Tahun 2008 Tentang Pornografi; Pasal 296 KUHP; Pasal 506 KUHP; Pasal 37 ayat (2) Peraturan Daerah Pemerintahan Kota Surabaya No. 2 Tahun 2014 tentang Penyelenggaraan Ketertiban Umum dan Ketentraman Masyarakat. Dalam penegakan hukum tindak pidana prostitusi online di Surabaya tidak hanya cenderung dengan memberikan sanksi sesuai dengan Pasal 27 ayat (1) Undang-Undang Informasi dan Transaksi Elektronik. Namun Pemerintah Kota Surabaya mencoba menerapkan pencegahan terhadap tindak pidana perdagangan orang yang dinilai mempunyai keterkaitan dengan tindak pidana prostitusi online. Dalam kebijakan pencegahan tindak pidanak perdagangan orang Pemerintah Kota Surabaya menerapkan dua sistem pencegahan yaitu pencegahan preemtif dan pencegahan preventif.
\end{abstract}

Kata Kunci: Tindak Pidana, Prostitusi Online, Penegakan Hukum 


\section{Pendahuluan}

\subsection{Latar Belakang}

Pelacuran identik dengan kata dalam Bahasa Latin prostitution, diartikan sebagai perilaku yang terang-terangan menyerahkan diri kepada perzinahan. Sementara itu, perzinahan diartikan sebagai perbuatan percintaan sampai bersetubuh antara seseorang yang telah berkeluarga (baik isteri maupun suami) dengan orang lain yang bukan isteri atau suaminya. Pengetian dari prostitusi sendiri ialah kegiatan seorang wanita atau pria yang rela melakukan hubungan seksual sebagia mata pencahariannya untuk mendapatkah bayaran dari orang yang menggunakan jasanya. ${ }^{1}$

Prostitusi merupakan kegiatan yang dianggap melanggar beberapa nilai kesopanan, kesusilaan, agama bahkan nilai-nilai moral. Kegiatan prostitusi dianggap bertentangan dengan adat istiadat yang ada di Indonesia yang selalu memegang teguh nilai-nilai kesopanan dan kesusilaan. Selain itu dengan adanya kegiatan prostitusi dianggap bisa mengakibatkan kerugian bagi penyedia jasa prostitusi dan pengguna jasa prostitusi itu sendiri. Hal ini dikarenakan dengan adanya prostitusi sama saja mendukung adanya seks bebas yang dapat mengakibatkan terinfeksi penyakit HIV dan AIDS. ${ }^{2}$

Indonesia sejatinya menolak adanya sebuah prostitusi, hal ini dapat dibuktikan adanya beberapa aturan yang mengatur larangan adanya praktek prostitusi. Salah satu peraturan yang mengatur tentang larangan praktik prostitusi adalah Pasal 506 Kitab Undang-Undang Hukum Pidana (yang selanjutnya disebut KUHP), Pasal 289 KUHP, Undang-Undang No. 35 Tahun 2002 Juncto Undang-Undang No. 35 Tahun 2014 Tentang Perlindungan Anak, dan masih banyak lagi peraturan yang melarang adanya praktik prostitusi di Indonesia. Namun dengan adanya peraturan mengenai larangan praktik prostitusi tersebut nyatanya masih belum bisa meminimalisir tingginya angka prostitusi di Indonesia kususnya di Surabya. Hal ini dikarenakan masih banyak masyarakat di Indonesia yang berasumsi bahwa mencari uang melalui jasa praktik prostitusi lebih mudah dibandingkan dengan cara yang lainnya. ${ }^{3}$

Pemerintah di Indonesia terus berupaya untuk menekan tingginya angka prostitusi di Indonesia. Salah satu usaha pemerintah di Indonesia adalah dengan menutup beberapa tempat praktik jasa prostitusi. Penutupan tempat praktik prostitusi salah satunya dilakukan oleh Walikota Surabaya Tri Rismaharini. Pada hari Kamis, 19 Juni 2014 Walikota Surabaya menutup salah satu kawasan prostitusi gang Dolly yang dianggap sebagai kawasan terbesar di Surabaya, bhakan dikenal sebagai kawasan prostitusi terbesar di Asia Tenggara. ${ }^{4}$ Penutupan kawasan prostitusi Dolly diharapkan dapat memperbaiki kondisi psikologis anak-anak disekitar kawasan Dolly. Selain itu

${ }^{1}$ Djubaedah. (2010). Perzinaan Dalam Peraturan Perundang-Undangan di Indonesia

Ditinjau Dari Hukum Islam. Jakarta: Kencana Prenada Media Grup, hlm. 15

${ }^{2}$ Kartono,K. (1981). Patologi Sosial. Jakarta: Rajawali Pers, hlm. 100-101

${ }^{3}$ Op.cit, hlm. 10

${ }^{4}$ https://regional.kompas.com/read/2014/06/18/2154086/Gang.Dolly.Resmi.Ditutup, diakses pada tanggal 15 Juni 2020, pada pukul 01.37 WIB 
penutupan kawasan prostitusi Dolly ini dilakukan dengan harapan untuk menkan tingginya angka prostitusi di Indonesia kususnya di kota Surabaya. Namun nyatanya penyedia jasa prostitusi masih bisa melakukan jasa prostitusi, beberapa kawasan prostitusi sudah ditutup.

Penyedia jasa prostitusi masih bisa membuka praktik jasa prostitusi dengan menggunakan kecanggihan teknologi yang ada. Meskipun tempat yang biasanya dipergunakan untuk membuka praktik jasa prostitusi sudah ditutup, namun penyedia jasa prostitusi saat ini bisa menggunakan kecanggihan teknologi berupa jaringan internet. Melalui beberapa akun media sosial dan beberapa kecangghian tekonologi digital para pengguna jasa prostitusi masih bisa memuaskan hasrat nya dengan beberapa macam cara. Jasa prostitusi melalui teknologi media sosial dan beberapa kecanggihan ini biasa disebut dengan jasa prostitusi online.

Jasa prostitusi online sampai saat ini semakin banyak dan tersebar di beberapa kawasan, dan tidak bisa dilihat dengan kasat mata. Dengan tingginya jasa prostitusi online di Surabaya dan tidak lagi terlihat dengan kasat mata transaksi prostitusi online menjadi permasalahan baru bagi aparat penegak hukum di Indonesia.

\subsection{Rumusan Masalah}

Berdasarkan latar belakang tersebut diatas telah dikemukakan, maka permasalahan dalam penelitian ini adalah sebagai berikut:

a. Bagaimana pengaturan hukum tindak pidana prostitusi online?

b. Bagaimana upaya penegakan hukum dalam kasus tindak pidana prostitusi online di Surabaya?

c. Mengapa dibutuhkan penegakan hukum tindak pidana prostitusi online di Surabaya?

\section{Metode Penelitian}

Metode yang digunakan untuk penelitian ini adalah metode normative, dari fakta-fakta dilapangan akan dicari permasalahan yang muncul dalam tindak pidana prostitusi online. Kemudian permasalahan tersebut akan dielaborasikan dengan beberapa sumber hukum pidana diantaranya peraturan perUndang-Undangan; dogmatika hukum; teori hukum; dan doktrin mengenai hukum pidana. Dengan begitu akan ditemukan sebuah solusi yang tepat untuk menyelesaikan permasalahan mengenai penegakan tindak pidana prostitusi online.

Metode penelitian yang digunakan pada saat ini mengacu pada argumentasi Philipus M. Hadjon. Dimana Philipus M. Hadjon menyatakan bahwa harus adanya keselarasan antara hukum yang tertulis ( $\mathrm{Law}$ in the book) dengan hukum yang ada dilapangan (Law in the action). ${ }^{5}$ Dengan begitu dalam pembahasan yang ada dalam ini pada awalnya akan membahas mengenai hukum yang tertulis yang diambil dari beberapa sumber hukum. Selanjutnya penelitian ini akan membahas mengenai hukum yang berlaku dilapangan. Ketika ditemukan ketidak selarasan antara hukum yang tertulis dengan hukum yang ada dilapangan maka hal tersebut menjadi titik permasalahan. Permasalahan yang ada kemudian akan dibahas dengan beberapa sumber hukum yang terkait dengan penelitian ini. Dengan demikian dapat ditemukan

\footnotetext{
${ }^{5}$ Hadjon,P.M. dan Sri,T. (2005). Argumentasi Hukum. Yogyakarta: UGM Pers, hlm.3
} 
bebrapa solusi yang tidak bertentangan dengan hukum yang ada. Hal ini dikarenakan ketika sebuah solusi masih bertentangan dengan hukum maka akan menimbulkan sebuah permasalahan yang baru.

\section{Hasil dan Pembahasan}

\subsection{Pengaturan Tentang Tindak Pidana Prostitusi Online}

Indonesia adalah negara hukum, dimana hal tersebut termaktub dalam Pasal 1 ayat (3) Undang-Undang Dasar Negara Republik Indonesia Tahun 1945. Sebagai negara hukum maka sudah seharusnya menjunjung tinggi keadaulatan hukum (supremacy of law). Selain itu sebuah negara hukum, maka dalam penyelenggaraan negara yang baik ialah harus didasarkan pada sebuah pengaturan yang baik. ${ }^{6}$ Dengan adanya sebuah peraturan maka diharapkan dapat menghindarkan dari segala kesewenang-wenangan punguasa, sehingga tidak ada lagi pemberian hukuman atau sanksi yang tidak memnuhi rasa keadilan, oleh karena itu diciptakanlah sebuah hukum pidana yang diharapkan dapat memberikan sebuah keadilan bagi seseorang yang dianggap melakukan sebuah tindak pidana.

Hukum pidana merupakan sebuah peraturan yang bersifat publik, dimana seseorang yang melakukan sebuah tindak maka akan diberikan sanksi sesuai dengan ketentuan yang telah ditulis dalam sebuah peraturan perundang-undangan. Tujuan dari hukum pidana sendiri diantarnya untuk mencegah suatu tindak pidana yang akan terjadi dengan cara menakut-nakuti seseorang yang akan melakukan sebuah tindak pidana. Selain itu tujuan hukum pidana adalah untuk memberikan efek jera bagi seseorang yang telah melakukan sebuah tindak pidana dengan memberikan sanksi untuk pelaku tindak pidana. Dengan adanya hukum pidana maka diharapakan akan terciptanya sebuah kedamaian dan ketentraman dalam kehidupan bermasyarakat. ${ }^{7}$

Ketentraman dan kedamaian merupakan sebuah tujuan hidup setiap warganegara, dimana hal tersebut akan bisa terjadi bila terwujudnya sebuah ketertiban umum, namun sampai saat ini ketertiban umum masih belum bisa terwujud dikarenakan adanya beberapa faktor. Dimana salah satu faktor tidak terwujudnya ketertiban umum adalah masih adanya sebuah praktik prostitusi. ${ }^{8}$

Prostitusi dianggap dapat memberikan sebuah dampak yang sangat negatif bagi setiap masyarakat di Indonesia khususnya di Surabaya. Salah satu dampak negatif dari adanya sebuah praktik prostitusi adalah merusak moralitas setiap masayarakat yang terpengaruh terhadap adanya sebuah praktik prostitusi. Meskipun saat ini tempat prostitusi sudah banyak yang sudah di tutup namun para penyedia jasa proatitusi saat ini masih bisa beraksi dengan menggunakan kecanggihan teknologi internet atau biasai disebut prostitusi online.

${ }^{6}$ Qamar,U. (2013). Hak Asasi Manusia dalam Negara Hukum Demokrasi. Jakarta: Sinar Grafika, hlm. 24

${ }^{7}$ Santoso,T. dan Zulva, E.A. (2010). Kriminologi. Jakarta: Raja Grafindo, hlm. 9

${ }^{8}$ Chazawi,A. (2005). Tindak Pidana Mengenai Kesopanan. Jakarta: Rajawali Pers, hlm.4 
Prostitusi online biasanya memanfaatkan beberapa media sosial seperti Whatsapp, Facebook, Instagram, dan lain-lain. Selain itu prostitusi online terkadang juga memanfaatkan aplikasi seperti Bigo live, dan aplikasi pencarian jodoh. Dengan adanya prostitusi online semakin membuat resah masyarakat Indonesia. Hal tersebut dikarenakan pada saat ini banyak anak dibawah umur sudah bisa mengakses internet. Dengan begitu maka hadirnya prostitusi online dapat merusak moralitas anak-anak.

Moral dan hukum merupakan dua sisi mata uang, dimana yang satu dapat menjustifikasikan yang lain. Moral dapat menjadi basis bagi hukum untuk menetapkan dan menjalankan kaidah-kaidahnya, oleh karena itu ketika sebuah perbuatan manusia sudah dianggap merusak moral, sudah selayaknya ada sebuah peraturan yang berfungsi untuk melerang seseorang melakukan perbuatan yang dianggap merusak moral termasuk kegiatan prostitusi online. ${ }^{9}$

Prostitusi online jika dilihat secara sekilas memanglah tidak mempunyai dampak yang sangat signifikan terhadap orang lain, namun prostitusi online tetap dianggap tidak benar karena hal tersebut bertentangan dengan beberapa kaidah termasuk kaidah kesusilaan dan kesopanan. HLA Hart dalam bukunya menjelaskan bahwa moralitas dibagi menjadi dua aliran yaitu moralitas ekstreme dan moralitas moderat. Moralitas ekstreme menyatakan bahwa pelanggaran moral haruslah ditegakkan oleh hukum (diberikan sanksi hukum). Meskipun barangkali dengan pelanggaran moral tersebut tidak ada atau belum ada pihak yang dirugikan. Misalnya terhadap pelanggaran moral dalam hubungan seks yang dilakukan oleh sesame jenis. Menurut HLA Hart tersebut perlu diberikan sanksi, karena hal tersebut secara tidak langsung dapat merusak moral dari seseorang, dan kemungkinan bisa ditirukan oleh orang lain. ${ }^{10}$

Tolok ukur sebuah perbuatan yang dikategorikan pelanggaran moral dan dapat diberikan sanksi adalah pelanggaran moral transedental (supernatural); pelanggaran moral intuitif; pelanggarn moral logis/naturalistic, pelanggaran moral pragmatis; dan pelanggaran moral nonkognitif. Sedangkan jika diamati secara lebih detail prostitusi online merupakan sebuah kegiatan atau perbuatan yang dianggap bertentangan dengan pelanggaran moral supernatural. Dimana adanya prostitusi online dianggap bertentangan dengan hukum Tuhan. ${ }^{11}$

Thomas Aquinas dalam teori hukum kodrat menjelaskan bahwa Hukum yang paling baik adalah hukum yang mendekati hukum Tuhan. ${ }^{12}$ Jika melihat penjelasan diatas maka sudah sepatutnya ada sebuah aturan yang mengatur tentang larangan adanya prostitusi online. Hal ini dikarenakan baik prostitusi dengan cara menggunakan cara apapun bertentangan dengan hukum Tuhan (agama). Prostitusi online memanglah sangat bertentangan dengan moralitas ekstreme yang dijelaskan

${ }^{9}$ Alam,A.S. (2010). Pengantar Kriminologi, Makassar: Pustaka Refleksi Books, hlm.6

${ }^{10}$ Hart,H.L.A. (2013). Konsep Hukum - The Concept of Law. Yogyakarta: Nusamedia. hlm.41

${ }^{11}$ Utari,I.S. (2012). Aliran dan Teori Dalam Kriminologi. Yogyakarta: Thafa Media, hlm. 7-8

12 Sumaryono,Y.E. (2002). Etika \& Hukum (Relevansi Teori Hukum KodratThomas Aquinas), Kanisius, Yogyakarta, hlm. 5-6 
oleh HLA. Hart ataupun teori hukum kodrat yang dijelaskan oleh Thomas Aquinas. Oleh karena itu terdapat beberapa aturan yang melarang adanya prostitusi online.

Pasal 27 ayat (1) Undang-Undang Nomor 11 Tahun 2008 tentang Infomarsi dan Transaksi Elektornik yang mengatur tentang penditribusian informasi atau dokumen elektronik yang mengandung unsur pelanggaran kesusilaan. Pasal 45 ayat (1) UndangUndang No. 19 Tahun 2016 tentang Informasi dan Transaksi Elektronik yang mengatur tentang sanksi bagi seseoarang yang melaanggar Pasal 27 ayat (1) Undang-Undang No. 1 Tahun 2018.

Pasal 4 ayat (2) Undang-Undang Nomor 44 Tahun 2008 tentang Pornografi, yang mengatur tentang larangan menyediakan jasa pornografi yang menyajikan secara eksplisit ketelanjangan; mengeksploitasi atau memamerkan aktivitas seksual; atau menawarkan atau mengiklankan layanan seksual. Pasal 296 KUHP yang mengatur tentang larangan adanya jasa praktik prostitusi. Pasal 506 KUHP yang mengatur mengenai mucikari. Selain peraturan tersebut masih ada beberpa peraturan ditingkat daerah yang melarang adanya sebuah jasa praktik prostitusi kususnya daerah Surabaya.

Pasal 37 ayat (2) Peraturan Daerah Pemerintahan Kota Surabaya No. 2 Tahun 2014 tentang Penyelenggaraan Ketertiban Umum dan Ketentraman Masyarakat yang mengatur tentang larangan seseorang menjadi Pegawai Seks Komersil (yang selanjutnya disebut PSK). Dengan adanya beberapa peraturan yang mengatur tentang larangan prostitusi diharapkan bisa menekan tingginya angka prostitusi di Indonesia.

\subsection{Penegakan Hukum Tindak Pidana Prostitusi Di Surabaya}

Lawrance M Friedman dalam teorinya menjelaskan bahwa tolok ukur sistem hukum yang baik terbagi menjadi tiga yaitu struktur hukum (structure of law), substansi hukum (substance of law), dan budaya hukum (legal culture). ${ }^{13}$ Struktur hukum dalam sebuah sistem hukum terdiri dari beberapa lembaga-lembaga yang melaksanakan sebuah peraturan baik peraturan formil maupun materiil. Selain pelaksanaan sebuah peraturan, hal yang termasuk dalam struktur hukum adalah lembaga penegakan hukum yang terdiri lembaga peradilan ataupun aparat penegak hukum non peradilan seperti kepolisian, satuan polisi pramong praja dan lain-lain.

Substansi hukum dalam sebuah sistem hukum adalah membahas mengenai peraturan perUndang-Undangan yang ada didalam sebuah negara ataupun wilayah. Peraturan perUndang-Undangan tersebut haruslah memenuhi tiga tujuan hukum yaitu keadilan, kepastian, dan kemanfaatan. Selain itu sebuah peraturan perUndangUndangan harus ditulis dengan jelas dan penafsirannya tidak kabur. ${ }^{14}$

Budaya hukum dalam sebuah sistem hukum membahas mengenai sikap manusia dalam mentaati sebuah peraturan perUndang-Undangan yang telah ditetapkan. Budaya hukum, substansi hukum, dan strutur hukum mempunyai sifat kumulatif, dimana ketiga unsur tersebut haruslah terpenuhi untuk membuat sistem

${ }^{13}$ Friedman, L. M. (1984). Legal Culture and Welfare State, dalam Gunter Teubner (ed.), Dilemmas of Law in the Welfare State. Ney York: The Gunter \& Co., hlm. 15-16

14 Atmasasmita,R. (2010). Teori dan Kapita Selekta Kriminologi, Bandung: Refika Aditama, hlm. 31 
hukum yang baik. Hal tersebut juga berlaku dalam kasus prostitusi online, dimana peran aparat penegak hukum sangatlah mempunyai pengaruh besar terhadap usaha pemerintah untuk menurunkan tingginya angka prostitusi online di Indonesia kususnya di Surabaya.

Penegakan hukum dalam sebuah negara harus mencerminkan sebuah tujuan hukum yaitu kepastian hukum, keadilan dan kemanfaatan. Kepastian hukum dalam sebuah penegakan hukum tercermin dalam sebuah cara melakukan penegakan hukum yang sesuai dengan ketentuan yang telah diatur dalam Undang-Undang ataupun menerapkan sebuah aturan dalam sebuah permasalahan. Penegakan hukum haruslah benar-benar maemahami apa yang tertulis dalam peraturan perundang-undangan agar tidak terjadi kesalahan dalam proses pengakan hukum. ${ }^{15}$

Keadilan harus tercermin dalam setiap tindakan aparat penegak hukum, salah satu contoh adalah dengan cara menerapkan asas equlity before of law (semua orang dianggap sama dimata hukum). para penegak hukum tidak boleh memberi suatu keistimewaan tertentu bagi seseorang yang dianggap bersalah dan bertentangan dengan peraturan perundang-undangan, yang terakhir adalah kemanfaatan hukum, dimana penegak hukum memberikan sebuah manfaat bagi para pelaku tindak pidana. Salah satu contohya adalah memberikan efek jera kepada pelaku tindak pidana agar tidak melakukan kejahatan atau tindak pidana sehingga dapat memberi rasa aman bagi masyarakat. Ketiga hal tersebut haruslah dipenuhi oleh penegak hukum dalam menangani segala bentuk permasalahan tindak pidana begitupun dalam tindak pidana prostitusi online di Surabaya.

Penegakan hukum praktik jasa prostitusi online di Surabaya terdiri beberapa unsur, diantaranya: Satuan Polisi Pamong Praja; Kepolisian; tim satuan Reserse dan Kriminal Kepolisian Surabaya (yang selanjutnyan disebut Satreskrim); dan masyarakat. Polisi Pamong Praja dan Kepolisian diberikan wewenang untuk menertibkan secara langsung jika adanya sebuah praktik prostitusi baik secara offline ataupun online. selain itu polisi juga bisa diberikan kewenangan untuk melakukan penyelidikan atau penyidikan dalam mencari sebuah barang bukti adanya sebuah praktik prostitusi.

Tim satreskrim Surabaya diberkian wewenang untuk mencari informasi mengenai adanya praktik prostitusi online melalui media internet ataupun dengan melihat tingkah laku seseorang. Informasi yang didapat oleh satreskrim akan dijadikan alat bukti permulaan sebagai dasar polisi untuk melakukan penyelidikan, dan penyidikan. Yang terakhir adalah peran dari warga Surabaya, dimana warga Surabaya diberikan wewenang untuk melaporkan sebuah tingkah laku atau kejadian yang memerlukan bantuan salah satunya jika adanya sebuah pelanggaran asusila berupa adanya prostitusi online. Warga daapt melakukan pelaporan dengan menelfon nomer yang telah diberikan yaitu 112. Dengan peran dari masyarakat diharapkan bisa membantu untuk menekan tingginya angka prostitusi online di Surabaya.

Para penyedia jasa prostitusi online akan diberikan sanksi sesuai dengan Pasal 45 ayat (1) Undang-Undang No. 19 Tahun 2016 tentang Informasi dan Transaksi Online.

\footnotetext{
${ }^{15}$ Muladi, dan Arief,B.N. (1998). Teori-Teori dan Kebijakan Pidana, Bandung: Alumni,
} hlm. 148 
Sedangkan untuk PSK akan dikenakan sanksi sesuai ketentuan Pasal 37 ayat (2) Perda kota Surabaya Nomor 2 Tahun 2014, namun tidak semua PSK akan dikenakan sanksi sesuai ketentuan Perda tersebut, hal ini dikarenkan Pemerintah Kota Surabaya memahami bahwa tidak semua orang ditangkap ingin menjadi PSK, beberapa orang ada yang menjadi korban dari tindak pidana perdagangan orang (human trafficking), oleh karena itu para aparat penegak hukum membedakan menjadi dua klasifikasi yaitu korban perdagangan orang dan pelaku atau penyedia jasa prostitusi.

Korban perdagangan orang menurut Perda Kota Surabaya No. 1 Tahun 2014 tentang Pencegahan dan Penanganan Korban Perdagangan Orang adalah seseorang yang mengalami penderitaan psikis, mental, fisik, seksual, ekonomi dan/atau sosial yang diakibatkan tindak pidana perdagangan orang. Melihat pengertian tersebut maka dapat disimpulkan bahwa korban perdagangan orang adalah seseorang yang mengalami penderitaan dalam tindak pidana orang, hal tersebut termasuk seseorang yang dipaksa atau terpaksa menjadi PSK, oleh karena itu dalam penegakan hukum kasus prostitusi online diSurabaya, para penegak hukum harus memberikan hak-hak yang dimiliki seseorang yang menjadi korban tindak pidana perdagangan orang.

Pencegahan adanya sebuah tindak pidana perdagangan orang merupakan salah satu cara untuk menekan tingginya angka prostitusi online. Hal ini dikarenakan tindak pidana perdagangan orang mempunyai kaitan dengan tindak pidana prostitusi online. Dalam kebijakan pebcegahan tindak pidana perdagangan orang pemerintah Kota Surabaya menerpakan dua sistem pencegahan yaitu pencegahan preventive dan pencegahan preemtive.

Pencegahan preventive adalah upaya langsung yang dilakukan oleh Pemerintah Daerah untuk melakukan pencegahan perdagangan orang melalui pengawasan, perizinan, pembinaan dan pengendalian. Pencegahan preventive sendiri diatur dalam Pasal 7 Perda Kota Surabaya No. 1 Tahun 2014. Dimana pencegahan tersebut terdiri dari:
a. mengembangkan sistem penanganan yang efektif dan responsif;
b. pelayanan perizinan yang jelas, pasti dan rasional;
c. penyediaan sistem informasi yang lengkap dan mudah diakses;
d. melakukan pendataan, pembinaan dan meningkatkan pengawasan terhadap setiap PPTKIS dan korporasi;
e. melakukan pendataan dan memonitor terhadap setiap warga yang akan bekerja di luar daerah;
f. membangun jejaring melalui koordinasi dan kerjasama dengan aparatur penegak hukum, aparatur pemerintah, perguruan tinggi dan berbagai Lembaga Swadaya Masyarakat yang bergerak di bidang Hak Asasi Manusia; dan/atau
g. membuka pos-pos pengaduan adanya tindak pidana perdagangan orang;

Pencegahan preventive dilakukan untuk menekan tingginya angka tindak pidana perdagangan orang di Surabaya. Dengan memberikan pengawasan yang cukup ketat maka diharapkan ruang gerak para pelaku tindak pidana perdagangan orang dan para pelaku tindak pidana perdagangan orang semakin sempit. Dengan cara tersebutlah dianggap sebagai cara yang cukup ampuh untuk mencegah beredarnya tindak pidana perdagangan orang dan tindak pidana prostitusi online. 
Pencegahan preemtive adalah tindakan yang dilakukan oleh Pemerintah Daerah pada tingkat kebijakan dalam upaya mendukung rencana, program dan kegiatan dalam rangka peningkatan pembangunan kualitas sumber daya manusia. Pencegahan preemtive diatur dalam Pasal 6 Perda Kota Surabaya No. 1 Tahun 2014, dimana pencegahan tersebut meliputi:

a. Peningkatan jumlah dan mutu pendidikan, baik formal maupun non formal bagi masyarakat;

b. pembukaan aksesibilitas bagi masyarakat untuk memperoleh pendidikan, pelatihan, pendanaan, peningkatan pendapatan dan pelayanan sosial;

c. Fasilitasi penyediaan lapangan kerja bagi masyarakat;

d. Membangun partisipasi dan kepedulian masyarakat terhadap pencegahan perdagangan orang.

Pengembangan sumber daya manusia ini dilakukan oleh Pemerintah Kota Surabaya dengan tujuan agar para korban tindak pidana perdagangan orang kususnya para PSK bisa diterima oleh masyarakat dan mendapatkan sebuah pekerjaan. Selain itu dengan adanya pencegahan preemtive, maka diharapkan dapat mengubah pola pikir para PSK sehingga tidak melakukan atau membuka sebuah jaringan prostitusi. Dengan cara tersebut merupakan cara yang paling ampuh untuk menghentikan penambahan jumlah peredaran prostitusi baik dengan cara online maupun offline.

Penegakan hukum tindak pidana prostitusi online di Surabaya tidak akan cukup hanya dengan memberikan sanksi bagi pelaku atau PSKnya saja. Hal ini dikarenakan sebagai PSK masuk dalam dunia prostitusi merupakan sebuah penghasilan untuk memenuhi kebutuhan hidup mereka. Oleh karenanya dengan meningkatkan sumber daya manusia para PSK di Surabaya, dan memberikan sebuah lapangan pekerjaan untuk mereka merupakan salah satu cara yang dianggap tepat. Setidaknya dengan meningkatkan sumber daya manusia para PSK maka diharapkan PSK di Surabaya semakin sedikit dan membuat para penyedia jasa prostitusi online akan kekurangan pencaharian. Sehingga hal tersebut bisa menekan tingginnya angka prostitusi di Surabaya.

\subsection{Tujuan Penegakan Hukum Tindak Pidana Prostitusi Di Surabaya}

Prostitusi merupakan penyakit masyarakat yang sulit untuk diberantas karena banyak faktor yang mempengaruhi eksistensinya. Beragam tipe prostitusi yang muncul menunjukkan betapa perkembangan prostitusi telah menggurita di dalam masyarakat, termasuk di Surabaya. Banyak kalangan yang menganggap bahwa prostitusi adalah penyakit masyarakat yang harus dibasmi.

Prostitusi di Surabaya berkembang pesat sejalan dengan perkembangan kota. Baik prostitusi terselubung maupun yang terbuka, keduanya mendapat tempat dalam kota penting yang menjadi bagian sejarah bangsa Indonesia. Para penyedia jasa layanan seks tersebut seakan-akan tidak ada rasa malu lagi terhadap profesi yang dijalaninya. Banyaknya Pekerja Seks Komersil (PSK) di kota yang berjuluk Kota Pahlawan ini, hingga dapat diklasifikasi menjadi tiga bagian yakni: Prostitusi kelas rendah, prostitusi kelas menengah, hingga prostitusi kelas atas.

Kebijakan Pemkot Surabaya menutup lokalisai prostitusi Dolly disambut sikap pro dan kontra. Mereka yang kontra kebanyakan adalah pekerja Dolly yang terancam 
kehilangan mata pencaharian jika lokalisasi prostitusi ini ditutup. Sementara itu, yang mendukung kebanayakan warga di sekitar lokalisasi. Dampak negatif yang dimaksud antara lain berupa stigma negatif kepada warga sekitar lokalisasi serta mengganggu ketenangan warga sekitar. ${ }^{16}$

Dewan Perwakilan Rakyat Daerah (DPRD) Kota Surabaya menyatakan lokalisasi prostitusi Dolly harus ditutup. Karena menyebabkan generasi muda Surabaya, terutama anak-anak dan remaja menjadi korban keberadaan Dolly. Konsumen PSK di Dolly tidak hanya pria dewasa, melainkan juga generasi muda. ${ }^{17}$ Walikota Surabaya Tri Rismaharini mengungkapkan sedikitnya ada tiga hal yang menjadi alasan penutupan Dolly. Pertama, letak lokalisasi yang berabur dengan pemukiman masyarakat umum. Kedua, Peraturan daerah yang melarang perdagangan manusia. Ketiga, dampak sosial bagi anak-anak yang tinggal di skitar lokalisasi sangat buruk. ${ }^{18}$ Pemerintah Kota Surabaya dalam melakukan penutupan lokalisasi Dolly didasarkan pada Peraturan daerah Nomor 7 Tahun 1999 tentang Larangan Menggunakan Bangunan/Tempat untuk Perbuatan Asusila serta Pemikatan untuk Melakukan Perbuatan Asusila.

\section{Kesimpulan}

Permasalahan mengenai tindak pidana prostitusi online di Surabaya diatur dalam Pasal 27 ayat (1) Undang-Undang No. 11 Tahun 2008 tentang Informasi dan Transaksi Elektornik; Pasal 45 ayat (1) Undang-Undang No. 19 Tahun 2016 tentang Informasi dan Transaksi Elektronik; Pasal 27 ayat (1) Undang-Undang No. 1 Tahun 2018 tentang Informasi dan Transaksi Elektronik; Pasal 4 ayat (2) Undang-Undang No. 44 Tahun 2008 Tentang Pornografi; Pasal 4 ayat (2) Undang-Undang No. 44 Tahun 2008 Tentang Pornografi; Pasal 296 KUHP; Pasal 506 KUHP; Pasal 37 ayat (2) Peraturan Daerah Pemrintahan Kota Surabaya No. 2 Tahun 2014 tentang Penyelenggaraan Ketertiban Umum dan Ketentraman Masyarakat.

Penegakan hukum Tindak Pidana Prostitusi online di Surabaya tidak hanya cenderung dengan memberikan sanksi sesuai dengan Pasal 27 ayat (1) UndangUndang Informasi dan Transaksi Elektronik. Namun Pemerintah Kota Surabaya mencoba menerapkan pencegahan terhadap tindak pidana perdagangan orang yang dinilai mempunyai keterkaitan dengan tindak pidana prostitusi online. dalam kebijakan pencegahan tindak pidana perdagangan orang Pemerintah kota Surabaya menerapkan dua sistem pencegahan yaitu pencegahan preventive dan pencegahan preemtive.

Prostitusi di Surabaya yang berkembang semakin pesat membawa dampak yang negatif, antara lain berupa stigma negatif terhadap warga yang tinggal di sekitar lokalisasi Dolly, dampak negatif sosial, dan dampak negatif bagi generasi muda.

${ }^{16}$ https://regional.kompas.com/read/2014/06/16/1649550/Cerita.Warga.yang.Terda mpak.Stigma.Negatif.Gang.Dolly, diakses pada tanggal 23 Desember 2010, diakses pada pukul 15.30 WIB

${ }^{17}$ https://republika.co.id/berita/nasional/jawa-timur/14/05/26/n65cgk-ini-alasanlokalisasi-dolly-harus-ditutup, diakses pada tanggal 23-Desember-2020, diakses pada pukul 16.00 WIB

${ }^{18}$ https:// daerah.sindonews.com/berita/861540/23/3-alasan-risma-ngotot-tutup-dolly, diakses pada tanggal 23-Desember-2020, diakses pada pukul 16.15 WIB 
Sehingga untuk mencegah dan mengatasi dampak negatif yang terjadi, Pemerintah Kota Surabaya melakukan penutupan lokalisasi Dolly dengan berdasar juga pada peraturan perUndang-Undangan yang berlaku.

\section{Saran}

Berdasarkan penelitian yang saya lakukan, maka saran yang dapat saya sampaikan adalah sebagai berikut;

a. Untuk mengurangi munculnya kejahatan prostitusi online dapat membuat aturan yang tegas mengenai kehajatan prostitusi, yang harus mengatur secara jelas dan tegas mengenai praktik pelacuran dan prostitusi. Hendaknya para penegak hukum lebih jeli dalam proses penyidikan untuk menentukan yang mana korban karena tipu muslihat mucikari, dan yang memang sukarela untuk bergabung dalam jaringan prostitusi online.

b. Perlu adanya upaya pembenahan khususnya dibidang teknologi dan informasi pada struktur penegak hukum agar secara cepat dapat menangani kasus yang berhubungan dengan teknologi dan informasi. Kepada masyarakat hendaknya ikut serta membantu penegak hukum dalam melaporkan dan menertibkan prostitusi melalui media elektronik.

c. Perlu dilakukan peran serta aktif dan dukungan masyarakat, khususnya masyarakat Kota Surabaya agar tidak ada lagi praktik prostitusi di Kota Surabaya berdampak negatif. Penegak hukum harus secara serius dan tidak tebang pilih dalam melakukan penertiban terhadap praktik prostitusi

\section{DAFTAR PUSTAKA}

\section{A. Buku}

Alam, A.S. (2010). Pengantar Kriminologi, Makassar: Pustaka Refleksi Books.

Atmasasmita, R. (2010). Teori dan Kapita Selekta Kriminologi, Bandung: Refika Aditama.

Chazawi, A. (2005). Tindak Pidana Mengenai Kesopanan. Jakarta: Rajawali Pers.

Djubaedah, (2010). Perzinaan Dalam Peraturan Perundang-Undangan di Indonesia Ditinjau Dari Hukum Islam, Jakarta: Kencana Prenada Media Grup.

Hart, H.L.A. (2013). Konsep Hukum - The Concept of Law, Yogyakarta: Nusamedia.

Hull, T.H., Sulistianingsih, E., Jones,G.W. (1997). Pelacuran Di Indonesia, Jakarta: Pustaka Sinar Harapan.

Kartono, K. (1981). Patologi Sosial, Jakarta: Rajawali Pers.

Santoso, T., Zulva,E.A. (2010). Kriminologi, Jakarta: Raja Grafindo.

Sumaryono, Y.E. (2002). Etika \& Hukum (Relevansi Teori Hukum KodratThomas Aquinas), Yogyakarta: Kanisius.

Utari, I.S. (2012). Aliran dan Teori Dalam Kriminologi, Yogyakarta: Thafa Media. 
Qamar ,U. (2013). Hak Asasi Manusia dalam Negara Hukum Demokrasi, Jakarta: Sinar Grafika.

\section{B. Peraturan Perundang-Undangan}

Kitab Undang-Undang Hukum Pidana

Undang-Undang No. 44 Tahun 2008 tentang Pornografi

Undang-Undang No. 1 Tahun 2018 tentang Informasi dan Trnasksi Elektronik

Peraturan Daerah Kota Surabaya No. 7 Tahun 1999 tentang Larangan Menggunakan Bangunan/Tempat untuk Perbuatan Asusila serta Pemikatan untuk Melakukan Perbuatan Asusila

Peraturan Daerah Kota Surabaya No. 1 Tahun 2014 tentang Pencegahan Dan Penanganan Korban Perdagangan Orang

Peraturan Daerah Pemrintahan Kota Surabaya No. 2 Tahun 2014 tentang Penyelenggaraan ketertiban Umum dan Ketentraman Masyarakat

\section{INTERNET}

https://regional.kompas.com/read/2014/06/18/2154086/Gang.Dolly.Resmi.Ditutup https://regional.kompas.com/read/2014/06/16/1649550/Cerita.Warga.yang.Terdam pak.Stigma.Negatif.Gang.Dolly

https://republika.co.id/berita/nasional/jawa-timur/14/05/26/n65cgk-ini-alasanlokalisasi-dolly-harus-ditutup

https://daerah.sindonews.com/berita/861540/23/3-alasan-risma-ngotot-tutup-dolly 